\title{
EFFORTS TO MINIMIZE STRESS IN ADOLESCENTS THROUGH GOING FOR COFFEE "NGOPI" IN MALANG CITY
}

\author{
Windi Chusniah Rachmawati ${ }^{1}$, Fitri Khalimiah ${ }^{1}$, Endang Sri Redjeki ${ }^{2}$ \\ ${ }^{1}$ Department of Public Health Sciences University of Malang \\ ${ }^{2}$ Outside School Education, Faculty of Education, State University of Malang \\ Correspondence address: Windi Chusniah Rachmawati \\ Email: windichusniah92@gmail.com
}

\begin{abstract}
There are a large number of teenagers in the world who experience mental health problems as a result of stress, which disrupts human productivity. A good mental state allows people to realize the potential that exists in themselves, overcome the stresses of life, work productively, and contribute to their community. The purpose of this study was to describe efforts to minimize stress among adolescents by going for coffee in Malang city. This research was descriptive with a quantitative approach. Data was obtained through direct observation and interviews with respondents based on research guidelines. Stress minimization refers to the reduction of stress or actions taken when experiencing stress to calm the mind, which can be done by seeking peace, drinking coffee, and hanging out with friends. Managing stress in adolescents is important because it will affect the next stage of their lives. If adolescents cannot manage stress properly, they will continue to think about it and their performance will not be optimal. The attitude taken when having a problem that disturbs the mind can vary, such as worshipping first then looking for the source of the problem. Alternatively, taking a walk and drinking coffee can calm the mind. Doing assignments in a coffee shop rather than in a boarding house is more productive and allows for many ideas to arise.
\end{abstract}

Keywords: stress, reducing stress, coffee shop, teenage age

\begin{abstract}
ABSTRAK
Sebagian besar penduduk usia remaja di dunia mengalami gangguan kesehatan mental akibat stres yang menyebabkan terganggunya produktivitas manusia. Namun, keadaan mental yang baik memungkinkan orang untuk menyadari potensi yang ada pada dirinya, mengatasi tekanan kehidupan, bekerja secara produktif, dan ikut berkontribusi pada komunitas baik dalam lingkup kecil atau besar. Penelitian ini bertujuan untuk menggambarkan upaya meminimalisir stres melalui perilaku ngopi pada kalangan remaja di Kota Malang. Penelitian ini menggunakan jenis penelitian deskriptif dengan pendekatan yang berupa pendekatan kuanlitatif. Perolehan data pada penelitian ini melalui observasi dan wawancara dengan informan secara langsung berdasarkan pedoman penelitian. Minimalisasi stres merupakan cara bagaimana seseorang mengurangi stres atau tindakan yang dilakukan ketika mengalami stres untuk menenangkan pikiran, seperti mencari ketenangan, ngopi, dan kumpul bersama teman-teman. Pengelolaan stres di kalangan remaja merupakan hal penting karena akan berpengaruh dengan kehidupan selanjutnya. Ketika remaja tidak dapat mengelola stres dengan baik, maka mereka akan terus tertekan terus menerus dan tidak maksimal dalam melakukan tugas. Sikap yang diambil untuk menghadapi masalah cukup besar bermacam-macam, seperti melakukan ibadah terlebih dahulu kemudian mencari sumber masalahnya. Jika seorang remaja belum merasa tenang, maka mereka memilih jalan-jalan dan ngopi untuk menenangkan pikiran. Mereka dapat mengerjakan tugas di warung atau kafe kopi daripada sendiri di kost, sehingga mereka lebih produktif dan menghasilkan banyak ide.
\end{abstract}

Kata kunci: stres, mengurangi stres, kedai kopi, usia remaja

\section{INTRODUCTION}

Adolescence is known as the most enjoyable period, as during this time teenagers begin to look for their identity and seek for new experiences interesting or challenging. The adolescent phase is also a developmental phase, which can be a very vulnerable and critical period if not properly managed. This period is called the period of preparation for adulthood, where the stages of development are very important in shaping how obstacles will be faced later on (World Health Organization (WHO), 2015). 
Adolescence is often associated with assumptions about deviance. Psychologists also label adolescence as a period of storm and stress. In regards to the socialization stage, adolescents are categorized as the game stage (ready to act) or recognize their role as individuals who are ready to go to the mature stage (maturity) (Sarwono, 2013). Therefore, the right time to improve attitudes and behavior is during adolescence, a period of improvement from the previous life stages. According to the National Population and Family Planning Board (BKKBN), adolescents are unmarried individuals between the ages of 10-24 years.

According to the National Coffee Association of the United States (2011), there was an increase in daily coffee consumers, the majority of which were teenagers aged 18-28 years. Many teenagers in Malang often spend time in coffee shops, and this has led to an increase in demand for coffee and variants of coffee in Indonesia. Indonesia is listed as the sixth largest coffee consumers in the world. Indonesia is also known for specialty coffee with unique flavors and aromas, and this is one of the factors driving the development of coffee shops in Indonesia (Indonesian Ministry of Agriculture, 2016) .

The increase in coffee production in Indonesia is also a factor in the emergence of various brands, cafes, and coffee shops in various shopping centers and other locations such as Malang, which is now known as the city of a million coffees. Even though there are many brands that have sprung up, entrepreneurs who are trying to enter the modern coffee shop industry have different market-share objectives.

According to teenagers, coffee drinking activities are not just a demand for taste but an activity to fill their spare time and release fatigue from their daily routine. They want a new atmosphere to refresh their mind by hanging out at coffee shops, enjoying coffee with friends, joking with each other, and exchanging stories while taking advantage of the free Wi-Fi rather than having to stay in their room or boarding house. This differs from the older generation's perspective that enjoying a cup of coffee is something people do every day in a coffee shop or at home in the morning before starting work.

Preliminary studies were carried out on several adolescents in one of the low-cost coffee shops with the random selection method. Some of these teenagers reported feeling fatigue (loss of enthusiasm, physical fatigue, lack of concentration) because of the piling up of assignments and school and college activities, and some were tired from working all day long; therefore, they chose to visit coffee shops because this activity calms their minds. The positive impact of getting coffee may be experienced when enjoying a cup of coffee is interspersed with a little discussion with friends. Fatigue, anxiety, and drowsiness then disappear, and people can return to concentrating on doing their next activity.

Coffee is not something new for Indonesian people. A phenomenon that we often see today is drinking coffee is no longer just for adults but has become a routine and habit for some youth today. Enjoying coffee processing, chatting, having discussions in a coffee shop as a medium for gathering, and expressing and exchanging information have become a way of life in Indonesia. In addition, along with the increasing standard of living and a shift in lifestyle for Indonesian, the behavior pattern of coffee consumption has also shifted in meaning, especially for adolescents whose coffee drinking activities have specific goals, such as drinking coffee while doing assignments, talking, meeting, and so on. In that way, the need for coffee drinking activities and obligations as a student or worker can be balanced.

This coffee drinking activity and the interactions that accompany it will have a wide and positive impact on adolescents. 
Participants stated that this activity was a habit that was underestimated, and there was an assumption that this activity was a culture for lazy people. They also stated that there was an assumption that this activity was a waste of time. However, there is also the positive outlook that this activity is a way for participants to calm themselves from the burden of the thoughts they face, and coffee shops are places for exchanging information that would not be obtained from academic activities. Therefore, this study aims to describe efforts to minimize stress through going for coffee among adolescents in Malang.

\section{METHODS}

The study used a qualitativedescriptive research method, collecting data in the written words or utterances from respondents and their observable behavior. The purposive sampling technique was used to select respondents based on the inclusion criteria, namely respondents aged 10-24 years who enjoyed going for coffee. Then, key respondents including coffee shop owners and friends of respondents were selected. Respondents were selected based on their explanations which were consistent with the research problem. Data were collected through in-depth interviews. Matching answers and triangulation were carried out by means of data reduction and displayed with a clustered concept matrix model. The saturation of the data was obtained after no different or new information was retrieved from the interview conducted with seven respondents and seven triangulation respondents. The list of questions given during the interview included questions about the description of coffee drinking behavior, knowledge of information about minimizing stress, the respondent's attitude towards stress, and the respondent's coffee-drinking behavior during the stressing moments. The researcher wanted to explore these questions in order to explain the phenomena consistent with the research problem. The number of respondents in this study was seven key respondents and seven triangulation respondents. This study used triangulation of data sources to test the credibility of the data that has been obtained through several sources. The triangulation process was carried out to the closest friends of the respondents to ensure that the data disclosed by respondents were accurate. This study produced descriptive data from respondents' answers by describing in deeper meaning of coffee for minimalizing stressful situations among teenagers in Malang, especially in the Amstirdam and Lupa Lelah coffee shops. This research was conducted among adolescents who went for coffee using the Rapid Assessment Procedure (RAP) study design, a procedure to obtain in-depth information about what causes behavior in public health. Primary data were obtained through observation and in-depth interview with the respondents for approximately one hour. This began with licensing to the respondents by providing an informed consent sheet, then followed by questions focused on knowledge, attitudes, and practices of the respondents when getting coffee. Respondents were characterized as active consumers if they visited coffee shops at least 2-3 times a week and enjoyed their coffee. While they were categorized as passive consumers if they inhaled the aroma of someone else's coffee. The respondents had to be 10-24 years old and were willing to become participants by signing on the informed consent sheet.

\section{RESULTS}

Malang is a city populated by many students because it is one of the cities of education in Indonesia as new students come to there every year, while the number of graduates is not proportional to that of new students. 
Data from the 2010 population census projection by the Central Statistics Agency (BPS) (2019) state that the population of Malang is 870,682 people with more than 60 universities spread across several regions. The number of undergraduate students in the State University of Malang, Brawijaya University, Health Polytechnic of Malang Ministry of Health and State Polytechnic of Malang reached 83,059 people in 2019. This made Malang the second most populous city in East Java after Surabaya, considering that there are still many universities that have not been listed in the BPS data.

Table 1. Number of Undergraduate Students (S1) in Malang during the 2018/2019 Academic Year

\begin{tabular}{|c|c|c|c|}
\hline $\begin{array}{c}\text { Universitie } \\
\mathbf{S}\end{array}$ & Males & $\begin{array}{c}\text { Female } \\
\mathrm{s}\end{array}$ & Total \\
\hline $\begin{array}{l}\text { Malang } \\
\text { State } \\
\text { University }\end{array}$ & 10,728 & 16,535 & 27,263 \\
\hline $\begin{array}{l}\text { Brawijaya } \\
\text { University }\end{array}$ & 23,086 & 25,844 & 48,930 \\
\hline $\begin{array}{l}\text { Health } \\
\text { Polytechnic } \\
\text { of Malang }\end{array}$ & 619 & 3,819 & 4,438 \\
\hline $\begin{array}{l}\text { State } \\
\text { Polytechnic } \\
\text { of Malang }\end{array}$ & 1,491 & 937 & 2,428 \\
\hline Total & 35,924 & 47,135 & 83,059 \\
\hline
\end{tabular}

Table 1 shows that Universitas Brawijaya had the largest number of undergraduate students in Malang with a total of 48,930 students, then followed by Malang State University with 27,263 students.

\section{Characteristics of respondents}

In determining key respondents, the researchers set several respondent criteria, one of which was being active consumers in the selected coffee shops. They then selected several respondents through the recommendations of baristas in each shop, and a total of 20 respondents were recommended. They then took as many as 15 samples to be potential respondents. After determining the prospective respondents, the researchers then made observations on the respondents to ensure they matched the criteria. Six people in total met the criteria based on their respective experiences and behaviors.

Table 2. Respondent Characteristics

\begin{tabular}{|c|c|c|}
\hline Characteristics & $\mathbf{n}$ & $\%$ \\
\hline \multicolumn{3}{|l|}{ Hometown } \\
\hline a. Malang & 3 & 50 \\
\hline b. Banyuwangi & 1 & 16.7 \\
\hline c. Tulungagung & 1 & 16.7 \\
\hline \multicolumn{3}{|l|}{ Age } \\
\hline a. 17 & 1 & 16.7 \\
\hline b. 22 & 2 & 33.3 \\
\hline c. 23 & 3 & 50 \\
\hline \multicolumn{3}{|l|}{ Gender } \\
\hline a. Male & 5 & 83.3 \\
\hline b. Female & 1 & 16.7 \\
\hline \multicolumn{3}{|l|}{ Level of occupation } \\
\hline a. High school & 1 & 16.7 \\
\hline b. Student & 2 & 33.3 \\
\hline c. Online ojek driver & 1 & 16.7 \\
\hline d. Content creator & 1 & 16.7 \\
\hline e. Private & 1 & 16.7 \\
\hline \multicolumn{3}{|l|}{ Started consuming coffee } \\
\hline a. 3 years ago & 2 & 33.3 \\
\hline b. 4 years ago & 1 & 16.7 \\
\hline c. 5 years ago & 1 & 16.7 \\
\hline d. 8 years ago & 1 & 16.7 \\
\hline e. 9 years ago & 1 & 16.7 \\
\hline \multicolumn{3}{|c|}{$\begin{array}{l}\text { Cups of coffee consumed in } \\
\text { a day }\end{array}$} \\
\hline a. 2 cups & 1 & 16.7 \\
\hline b. 3 cups & 4 & 66.6 \\
\hline c. 4 cups & 1 & 16.7 \\
\hline
\end{tabular}

Table 2 shows a half of the respondents $(50 \%)$ come from Malang city 
was adolescents aged 23 years $(50 \%)$, and the majority were males $(83.3 \%)$. Most respondents were students $(33.3 \%)$, started consuming coffee 3 years ago $(33.3 \%)$, and consumed 3 cups of coffee a day $(66.6 \%)$.

This study conducted a reconfirmation process by triangulating the closest person to the respondents who was considered to know the truth of the information they gave. The triangulation respondents were close friends of the respondents or accompanied the respondents to the coffee shop when the research was carried out.

Table 3. Relationship between Triangulation Respondents and Respondents

\begin{tabular}{lcc}
\hline Characteristics & n & \% \\
\hline $\begin{array}{l}\text { Relationship between } \\
\text { triangulation respondents } \\
\text { and respondents }\end{array}$ & & \\
a. Friend & 4 & 57.1 \\
b. Romatic partner & 1 & 14.2 \\
c. Neighbor & 1 & 14.2 \\
d. Shop owner & 1 & 14.2 \\
\hline Hometown & & \\
a. Malang & 5 & 71.4 \\
b. Banyuwangi & 1 & 14.2 \\
c. Ponorogo & 1 & 14.2 \\
\hline Age & & \\
a. 18 & 1 & 14.2 \\
b. 20 & 1 & 14.2 \\
c. 22 & 2 & 28.8 \\
d. 23 & 1 & 14.2 \\
e. 24 & 1 & 14.2 \\
f. 38 & 1 & 14.2 \\
\hline Gender & & \\
a. Male & 5 & 71.4 \\
b. Female & 2 & 28.8 \\
\hline Occupation & & \\
a. High school student & 1 & 14.2 \\
b. University Student & 2 & 28.8 \\
c. Online ojek driver & 1 & 16.7 \\
d. Content creator & 3 & 42.8 \\
\hline
\end{tabular}

\begin{tabular}{lcc}
\hline Characteristics & n & \% \\
\hline Started consuming coffee & & \\
a. 3 years ago & 1 & 16.7 \\
b. 4 years ago & 2 & 28.8 \\
c. 5 years ago & 2 & 28.8 \\
d. 9 years ago & 1 & 16.7 \\
e. 20 years ago & 1 & 16.7 \\
\hline
\end{tabular}

Table 3 shows that most triangulation respondents $(57.1 \%)$ were friends of the respondents, and most of them (71.4\%) originated from Malang city. Most of them $(28.8 \%)$ were 22 years old, male $(71.4 \%)$, and worked as content creators $(42.8 \%)$.

\section{Respondent description}

The results of this study describe the interopinion of all respondents regarding the respondents' behavior of getting coffee. The data include the first time of coffee drinking, frequencies of visits to the research site, how many times the respondent was vulnerable in one week, the frequency of coffee drinking, and experiences during coffee drinking. The questions in this study contained elements of knowledge, attitudes, and practices in coffee drinking activities.

\section{Respondents' first-time getting coffee}

All respondents were teenagers who were active in coffee consumption. Most of the respondents first tried coffee in high school or college, and there were even respondents that had been drinking coffee since junior high school. All respondents also stated that they had been getting coffee for 35 years.

The first respondent first had coffee in their second semester of university in 2016, and the second respondent started drinking coffee as university in 2017. The third respondent started drinking coffee in junior high school, and the fourth respondent started drinking sachet coffee in their second semester of junior high school in 2016. 
Moreover, the fifth respondent initially drank coffee in elementary school in 2008, and the sixth respondent started drinking coffee in university of semester 4 in 2017.

\section{Causes of coffee drinking}

The respondents drank coffee for the first time due to several different factors. Teenagers explore new activities such as drinking coffee due to curiosity, the influence of their environment, or boredom with their daily activities. Some expressed feelings of boredom and curiosity as the cause of their coffee habits, while others said it was due to an invitation from a friend. The first, second, fifth, and sixth respondents had coffee for the first time due to their boredom and curiosity about coffee, while the third and fourth respondents said it was due to an invitation from a friend.

Some respondents stated that they tried coffee due to curiosity, while other respondents stated that it was due to environmental influences or invitations from friends. Teenagers are highly curios about the environment around them and always want to know what their friends are experiencing (Diananda, 2018). In addition, friends are also very influential in the formation and development of individual behavior such as coffee drinking behavior. Friends, playmates, organizational friends, or coworkers are people who play a role in motivating individuals to do activities (Raihan et al, 2020). Teens also like to share experiences of intimacy and joy when getting to know new things and establishing relationships, including things that allow feelings of joy or disappointment into these relationships. Some other teenagers like to tell stories while getting together for coffee.

\section{Reasons for visiting the research sites}

The reasons for the respondents visiting the research site were the respondents stated that the atmosphere and coffee were good and the staff were friendly. Others were due to that the atmosphere was refreshing and the shop had affordable prices for teenagers. Anyone taking part in an activity will have a unique experience, especially pleasure. Pleasure is achieved when consumers get satisfaction from the consumption process, especially taste and service of cooked materials or processed foods, as well as the specific impression about a place (Warde, 2003). Besides, when someone is loyal to a particular product or brand, they become committed to repurchasing or subscribing to those products or services consistently in the future. It finally can lead to buying from the same brand repeatedly (Tjiptono and Fandy, 2015).

\section{Respondent description}

The results of this study describe the interopinion of all respondents regarding their habits in getting coffee. This includes the first time the respondents drank coffee, how many times they had visited the research site, how many times they were vulnerable in one week, how many times they have gotten coffee, and what the respondent had experienced because of coffee. The questions in this study contain elements of knowledge, attitudes, and practices in coffee drinking activities.

\section{DISCUSSION}

\section{First-time coffee drinking}

All respondents stated that they had been drinking coffee for about 3-5 years. The habit of drinking coffee in Indonesia is not new, but an increasing development has begun since 2002. Teenagers consider drinking coffee as a natural activity because western culture has entered Indonesia (Kartono and Demartoto, 2019). The phenomenon of this coffee drinking activity can be observed from how people can do an activity related to pleasure, priority, time, and opinion by considering it important to do. 
This activity provides adolescents with an experience in which individuals can find public spaces that tolerate differences in expression, perception, and culture, not only in the social sphere but also in the patterns and identities of individuals (Prasodjo, 2016).

\section{Reasons for drinking coffee}

Four respondents stated that the reason they started drinking coffee was their curiosity, while the other two respondents stated that it was due to environmental influences in the form of friends' invitations. Teenagers do have a high curiosity about the environment around them and always want to know what their friends are experiencing (Diananda, 2018). In addition, the influence of friends is also very influential in the formation and development of individual behavior such as in this coffee drinking activity, where friends are people who play a role in motivating individuals to carry out an activity, be it playmates, organizational friends or coworkers (Sarpin, 2020) Teens also enjoy telling stories about experiences of intimacy and joy when they get to know new things and build relationships, including things that allow feelings of joy or disappointment in these relationships. There are teenagers who like to tell stories so that they become one of the backgrounds for this coffee drinking activity. Besides that, teenagers drink coffee to relax themselves, gather with friends, and access Wi-Fi, or their keen of coffee (Nurikhsan, 2019). In accordance with the reasons, the shift in the coffee culture of teenagers today is due to changes in the purpose of coffee drinking. Lifestyles have developed to where each individual is now more concerned with the needs of groups and individuals than Physiological needs (SARTIKA, 2017).

\section{Knowledge of stress minimization}

Methods for minimizing stress in adolescents are paramount. Adolescents are a group of individuals who are susceptible to stress problems due to academic, family, and social environment pressures. Regarding knowledge of stress minimization, as many as five respondents and seven triangulation respondents explained that stress minimization is a person's way of reducing stress by controlling emotions or calming the mind to find solutions. Stress comes from self-emotion; therefore, stress minimization can be interpreted as self-awareness of emotions, ability to understand emotions, ability to use emotions well, ability to manage emotions, and ability to understand emotional messages in any events (Law and Lee, 2011). Meanwhile, one out of six respondents stated that their actions in minimizing stress included seeking peace, drinking coffee, and gathering with friends. Another respondent stated that stress was something normal, but it can cause something unnatural. The ability to solve problems is very important in the growth period and in the regulation of emotions in adolescents. When teenagers cannot overcome problems, it will result in insecurity, decreased achievement at school or work, and poor relationships with friends ,resulting in various problems or conflicts (Setianingsih et al, 2006). In accordance with the statements of the triangulation respondent, the ability to solve problems during adolescence can form a more mature attitude in controlling emotions and finding solutions to problems.

\section{Respondents' opinions regarding adolescent stress management}

Adolescents are individuals who experience many changes emotionally, intellectually, anatomically and physiologically during their developmental stage. All six respondents stated that managing stress during adolescence is something very important, and this statement was supported by triangulation data. This can be seen from the respondents' opinion and 
data triangulation that adolescence is a period of transition to adulthood. It is very important to develop self-control, know oneself, and learn to manage stress during adolescence because it will determine how a person will live the rest of their lives and goals they will achieve. Therefore, by successfully managing stress during adolescence, they will be more open-minded in solving problems, can recognize self-consistency in every activity to stay awake, and can control their emotions and stress. In doing these behaviors, they will be mentally stronger in dealing with the world of work and other problems in the future.

There is a relationship between good emotion management and stress levels in adolescents. It can be seen that the better adolescents manage emotionality, the lower they experience incidences of stress (Ahsan et al, 2018). Stress in adolescents can also affect several aspects such as physical, psychological, emotional, social, and spiritual conditions. Minimizing stress can be taken to manage environmental conditions and internal pressures that burden one's mind (Law and Lee, 2011). A tendency to have stress-related problems is the responsibility of every individual, and they need to apply good behavior, lifestyle, and stress management methods in daily activities. Therefore, controlling emotions is very necessary in handling stress properly.

\section{Coping strategies with problems}

Every individual experiences problems, both interpersonal and social. Each has their own way of dealing with or preventing their thoughts from dissolving in the problem. The average respondents stated that going for coffee was an alternative to calm the mind when they were running into problems. Four out of six respondents chose to get coffee to calm their minds because they needed friends to joke around with or exchange stories to receive feedback. The other two respondents did not always get coffee to calm their minds, and they preferred to just enjoy coffee alone with no friends. Friends are important for teenagers because they can share each other's secrets (Diananda, 2018). Having good friends plays an important role in shaping the thoughts and attitudes of adolescents, and it can affect their moral and spiritual well-being. According to one of the triangulation respondents, coffee functions only as a medium of calming thoughts, and each problem can be resolved depending on how each individual deals with it. Every individual has various coping strategies to deal with various pressures. Coping strategies serve two main functions, namely to regulate emotions and behavior that allows each individual to escape, change perceptions, tolerate, or minimize the pressures in order for the situation to be accepted, transferred, enhanced, or resolved (Lazarus et al, 1984).

\section{Activities undertaken during coffee drinking}

During coffee drinking, chatting with friends was the most favorable activity that the respondents always do. It is not uncommon as it can allow discussions to arise and share experiences. Besides, the respondents could also do assignments or work and have discussions while enjoying coffee and the atmosphere. One respondent also added that doing assignments while drinking coffee had a better productivity rate than doing them in their boarding house. The conversation carries on with different discussions and does not take a long time, and doing tasks or work is also easier at a coffee shop (Raihan et al, 2020). Enjoying coffee is now a habit that holds meaning for individuals, and drinking coffee is not only a fulfillment of life's needs but also a means of expressions. There are two specific motives for individuals to consume coffee, one of which is to relieve from a problem and ease their worry. Other motives are to eliminate 
boredom and fatigue, hang out with friends, exchange opinions, and enjoy the aroma and taste of coffee (Kartono and Demartoto, 2019).

\section{CONCLUSIONS}

Coffee is not something new and has become a new habit or routine for either adult or youth Indonesian. Enjoying coffee, chatting, and having discussions in a coffee shop as a medium of gathering, expressing, and exchanging information have become a way of life in Indonesia. Along with the increasing standard of living and a shift in lifestyle for Indonesians, the behavior pattern of coffee consumption also shifted in meaning. This is especially true for adolescents where coffee drinking activities have specific goals such as doing assignments, talking, and meeting friends. Thus, the consumers can balance the need for coffee drinking activities and obligations.

The results of this study show that there is a special meaning of coffee drinking activities in the city of Malang, a public space that has tolerance for differences in expression, perception, and culture. Many people still have negative perceptions about getting coffee among teenagers. Based on the results of this study, the community should play a role in increasing the exposure to the positive sides of getting coffee as a means of chats, storytelling, and information exchange. Coffee shops can also be spaces for the public to express inspiration and complaints, which will affect the social and emotional aspects of their mindset.

\section{REFERENCES}

Abdul M, G. (2019) 'Warung Kopi sebagai Ruang Ketiga bagi Pelajar SMA di Kecamatan Kragan Kabupaten Rembang', Jurnal Solidarity, 8(1), pp. 532-544. https://doi.org/10.36053/mesencephal on.v4i1.70

Ahsan, A. \& Ilmy, A. K. (2018) 'Hubungan Antara Pemenuhan Tugas Perkembangan Emosional Dengan Tingkat Stres Pada Remaja', J.K.Mesencephalon, 3, p. 3.

Diananda, A. (2018) 'Psikologi Remaja Dan Permasalahannya', Journal ISTIGHNA, (1), pp. 116-133. https://doi.org/10.33853/istighna.v1i 1.20

Kartono, \& Demartoto, A. (2019) 'Perilaku Konsumsi Kopi Sebagai Budaya Masyarakat Konsumsi: Studi Fenomenologi Pada Peminum Kopi Di Kedai Kopi Kota Semarang', Jurnal Analisa Sosiologi, 4(1), pp. 60-74.

Indonesian Ministry of Agriculture. (2016) Outlook Kopi Komoditas Pertanian Subsektor Perkebunan. Pusat Data Dan Sistem Informasi Pertanian Sekretariat Jenderal.

Law, B. M. F. and Lee, T. Y. (2011) 'Importance of emotional competence in designing an antidrug education curriculum for junior secondary school students in Hong Kong', TheScientificWorldJournal, 11, pp. 2257-2265. doi: 10.1100/2011/127894.

Lazarus, R, S \& Folkman, S. (1984) Stress, Appraisal and Coping. New York: Springer Publishing Company, Inc.

Nurikhsan., I. (2019) 'Fenomena coffee shop di kalangan konsumen remaja', Widya Komunika, 9 (2), pp. 137-144. https://doi.org/10.20884/1.wk.2019.9 .2 .1962

Prasodjo, A. (2016) 'Gaya Hidup Konsumen Warung Kopi di Wilayah Perkotaan Kabupaten Jember', Proseeding Seminar Nasional, pp. 133-143.

Raihan., Roslan, S., \& S. (2020) 'Berkunjung Di Warung Kopi Sebagai Gaya Hidup Masyarakat Kota', Jurnal Neo Societal, 5(1), pp. 1-13. 
Windi Chusniah Rachmawati, Fitri Khalimiah and Endang Sri Redjeki, Efforts To Minimize... 155

Sarpin, R. \& (2020) 'Berkunjung Di Warung Kopi Sebagai Gaya Hidup Masyarakat Kota', Jurnal Neo Societal, 5(1), pp. 1-13. doi: $10.1029 / 2019$ GH000237.

SARTIKA, R. (2017) 'Pergeseran Budaya Ngopi Di Kalangan Generasi Muda Di Kota Tanjungpinang', jurnal umrah, 91(5), pp. 1689-1699. doi: 10.1017/CBO9781107415324.004.

Sarwono, S. W. (2013) Psikologi Remaja. Jakarta: Rajawali Pers. https://doi.org/10.24854/jpu12012-6

Setianingsih, E, Z, Uyun \& S, Y. (2006)
'Hubungan Antara Penyesuaian Sosial Dan Kemampuan Menyelesaikan Masalah Dengan Kecenderungan Perilaku Delinkuen Pada Remaja', Jurnal Psikologi Universitas Diponegoro, 3(1), pp. 2935.

Warde, A. \&Lydia M. (2003) Eating Out: Social Differentiation, Consumption Adn Pleasure. Cambridge. Cambridge University Press.

WHO (2015) Adolescent Development. https://doi.org/10.1002/cad.20093 